\title{
Distinctive Characteristics of Small Businesses as Sites for Informal Learning
}

\author{
Alan Coetzer, Henrik Kock and Andreas Wallo \\ Journal Article
}

\section{Tweet}

N.B.: When citing this work, cite the original article.

Original Publication:

Alan Coetzer, Henrik Kock and Andreas Wallo, Distinctive Characteristics of Small Businesses as Sites for Informal Learning, Human Resource Development Review, 2017.

http://dx.doi.org/10.1177/1534484317704291

Copyright: SAGE Publications (UK and US)

http://www.uk.sagepub.com/home.nav

Postprint available at: Linköping University Electronic Press

http://urn.kb.se/resolve?urn=urn:nbn:se:liu:diva-136737

LINKÖPINGS

UNIVERSITET 


\title{
Distinctive Characteristics of Small Businesses as Sites for Informal Learning
}

\begin{abstract}
Few studies have examined workplace factors that influence informal learning in small businesses and in general the studies are not framed by the characteristics of small businesses. To address this weakness in existing literature we conducted a review of literatures which examine (a) workplace factors that influence informal learning; (b) small business characteristics; and (c) factors influencing informal learning in small businesses. The several workplace factors that influence learning were categorised as job, relational and organisational characteristics. Each category was examined in relation to characteristics of small businesses. We outline what is known about each category and what we need to learn about them as they relate to informal learning in small businesses. For each category propositions are generated that should be examined in future research. We also produce a heuristic conceptual framework that can be employed to focus and bound future research that tests a different set of propositions.
\end{abstract}

\section{Key words}

informal learning, small business, workplace learning

\section{Introduction}

The view that continuous learning is a key factor in the economic viability and competitive advantage of organisations (Aguinis \& Kraiger, 2009; Noe, Clarke \& Klein, 2014) and the suggestion that managers should facilitate the learning of staff (Hughes, 2004; Warhurst, 2013) has important implications for small businesses. This is because small businesses (broadly defined here as those employing 10-49 people) constitute a very major part of the workplacelearning context, since they are both numerically significant and major providers of employment in national economies (Muller et al., 2015). Given the substantial knowledge and skills base situated in small businesses, how employees in these organisations acquire new knowledge and 
skills through learning processes are matters of major interest (Billett, Hernon-Tinning \& Ehrich, 2003; Nolan \& Garavan, 2016a).

It is well documented that small businesses have a strong preference towards informal learning processes (Kitching, 2007; Nolan \& Garavan, 2016b) and are significantly less likely to provide their employees with access to employer-sponsored formal training and development (T\&D) opportunities than large businesses (Devins, Johnson \& Sutherland, 2004; Kotey and Folker, 2007; Kyndt \& Baert, 2013). However, although participation in formal T\&D events can make important contributions to learning, it is not the primary mode by which people learn in work organisations (Manuti, Pastore, Scardigno, Giancaspro \& Morciano, 2015; Noe et al., 2014). Informal modes of learning, such as learning through solving novel work problems and learning through interaction with more knowledgeable people in the workplace, account for most of employees’ work-related learning (Burns, Schaefer \& Hayden, 2005; Choi \& Jacobs, 2011). The effectiveness of informal learning is influenced by several workplace and personal factors (Noe, Tews \& Marand, 2013; Tannenbaum, Beard, McNall \& Salas, 2010). This paper focuses on workplace factors.

Despite the numerical and economic significance of small businesses in developed economies and their strong preference towards informal learning processes, few studies have examined workplace factors that influence informal learning in small businesses. Furthermore, these studies are generally not fine-tuned to the small business setting (Nolan \& Garavan, 2016b). There is wide agreement amongst scholars (d'Amboise \& Muldowney, 1988; Josefy, Kuban, Ireland \& Hitt, 2015; Paolillo, 1984; Welsh \& White, 1981) that small businesses are fundamentally different to large businesses. Thus, any attempt at elucidating distinctive characteristics of small businesses as sites for informal learning needs to consider fundamental differences between small and large businesses. We contend that a continued lack of careful attention to the specific nature of small businesses in studies which examine informal learning processes will impede the progress of this important research stream. 
This article follows Callahan’s (2010; 2014) and Torraco’s (2005; 2016) guidelines for writing literature reviews and its purposes are essentially twofold. First, we seek to highlight the weaknesses of prior empirical studies on workplace factors that influence informal learning in small businesses. This will be accomplished through a critical review of selected prior empirical research. Second, we wish to provide directions for future research on workplace factors that influence informal learning in small businesses. Importantly, these future research directions are framed within the context of distinctive characteristics of small businesses. This purpose will be achieved through an integration of literatures which examine (1) workplace factors that influence informal learning and (2) small business characteristics. Drawing on these two literature streams we develop a set of research propositions and generate a heuristic conceptual framework that can be employed to focus and bound future research that tests a different set of propositions.

The rest of the paper is structured as follows. In the following two sections we describe the key concepts of the paper, in particular 'informal learning' and 'small business'. Next, we critically analyse prior empirical studies on workplace factors that influence informal learning in small businesses. This is followed by an overview of literature on factors that influence informal learning in work organisations. Thereafter, we examine three broad categories of factors that influence informal learning in the context of small business and generate both research propositions and a heuristic conceptual framework. Finally, we outline limitations of the review and conclude the paper.

\section{Informal Learning and Types of Learning}

For purposes of investigating learning processes in workplaces, some learning theorists (e.g., Ellinger, 2005; Marsick \& Watkins, 1990) find it beneficial to distinguish between formal/structured and informal/unstructured learning situations. According to Eraut (2000, p.114), formal learning situations typically have the following characteristics: a prescribed learning framework; an organised learning event; presence of a designated instructor; award of 
a qualification or credit; and external specification of learning outcomes. In contrast, informal learning situations are frequently described as having the following characteristics: non-didactic; predominantly learner initiated and self-directed; socially collaborative; based on learning from experience; oriented to a focus on action; embedded in everyday goal-directed work activities and the organisational context; delimited by the nature of the task, the way in which problems are framed, and the work capacity of the individual undertaking the task; motivated by an intent to learn, improve and develop; and enhanced by pro-activity, critical reflection and creativity (Callanan, Cervantes \& Loomis, 2011, p.647; Tannenbaum et al., 2010, p. 306; Watkins \& Marsick, 1992, p.287). Incidental learning is deemed to be a subset of informal learning and it is usually the 'by-product' of activities such as carrying out a novel task or interacting with colleagues (Marsick \& Watkins, 1990). Lack of both the intention to learn and an awareness of learning is characteristic of incidental learning (Marsick \& Watkins, 1990).

A different perspective of workplace learning is adopted by researchers who focus on the magnitude of creative change involved in learning processes (Olsen, 2016). For example, Ellström (2001; 2010) and Fenwick (2003) distinguished between adaptive and innovative (or developmental) learning. Adaptive learning has its role primarily in formation of competencies for dealing with routine problems that are frequently occurring (Ellström, 2001; 2010). In adaptive learning the learner has to evaluate outcomes of the problem resolution process and make minor corrections in the way methods were used to solve the problem at hand (Ellström, 2001; 2010). This would, for example, apply to work settings where employees have responsibility for continuous improvement of formalised work procedures. Thus, adaptive learning encompasses small, bounded change (Fenwick, 2003). In contrast, in innovative learning, the learner has to engage in a more active process of knowledge-based problem solving through experimentation, risk-taking and variance seeking (Fenwick, 2003). Innovative learning is necessary when employees encounter novel or unfamiliar situations at work for which no rules or procedural knowledge ('know-how') is available from previous experience. This mode of 
learning also occurs when employees question and act to transform institutionalised ideologies, routines, structures or practices (Fenwick, 2003). Thus, innovative learning stimulates transformational change and generates novel solutions that challenge existing practices (Ellström, 2001; Fenwick, 2003).

\section{Defining the Small Business}

There is wide agreement in the literature that small businesses are fundamentally different to large businesses (e.g. Curran \& Blackburn, 2001; Josefy et al., 2015; Welsh \& White, 1981). Penrose (1959) made this point by using the analogy that small and large businesses are as fundamentally different from each other as caterpillars are from butterflies. Even if one metamorphoses into the other, it would not simply be a larger version of the other. Furthermore, there is no certainty that metamorphosis will take place at all. Therefore, any definition of the small business needs to capture the fundamental differences between small and large businesses.

Scholars have struggled to develop a theoretically meaningful definition of organisation size and there is no established, widely accepted, definition of what constitutes a small business (Curran \& Blackburn, 2001; Josefy et al., 2015). Qualitatively, a small business can be described as a business which is independently owned and managed by the same individual(s) and which is not dominant in its field of operation (Bolton, 1971; d'Amboise \& Muldowney, 1988). However, qualitative definitions of the small business are difficult to operationalise, consequently researchers often use quantitative criteria, such as number of employees or sales turnover, to operationalise the small business as a construct. In this paper, a business is defined as small if it has 10-49 employees. This definition of 'smallness' corresponds with the European Union definition of a small business (Muller et al,, 2015).

However, organisational size as measured by criteria such as the number of employees or sales turnover, often leads to ‘size reductionism’ (Curran \& Blackburn, 2001; Storey, 1994). This is a tendency among small business researchers to explain almost every aspect of the 
phenomenon being studied by reference to the size criterion that has been selected. According to Burrows and Curran (1989), "size, whether measured in terms of number of employees, turnover, market share or whatever, is not a sufficiently robust criterion to allow 'small firms' to be isolated and analysed as being an economic and social specificity” (p. 530). This is not to suggest that size has no influence, but only that it is just one of a wide array of internal and external contingency factors that can shape the firm (Nolan \& Garavan, 2016b). To help address these problems in defining a small business and arrive at a more satisfactory conceptualisation of the small business, we argue that research on informal learning in small businesses should focus on distinctive characteristics of small businesses that are potentially relevant to informal learning processes. Such a focus would also assist in bringing some coherence to research on informal learning in small businesses and enable comparisons to be made between countries and over time.

\section{Critical Analysis of Prior Research}

After reviewing literature published between 1973 and 2002 on learning in small businesses, Florén and Tell (2003) concluded that empirical research in this stream is sparse and that "the small-firm effect on learning needs to be further explored” (p. 56). To determine the state of research since Florén and Tell's (2003) study, we decided to review the more recent research literature. In the literature review undertaken for this paper, we followed guidelines provided by Callahan (2010; 2014) and Torraco (2005; 2016). The article inclusion criteria were as follows:

(a) empirical articles; (b) published in peer-reviewed journals; (c) during the period 2000-2016; (d) reporting research located in small businesses (10-49 employees); that (e) include a focus on informal learning. Keywords for the literature search included: 'small business', 'small firm', ‘small enterprise’, 'SME', 'informal learning', 'workplace learning', 'learning environment', 'learning climate', 'learning culture', ‘conditions for learning', 'learning orientation', and combinations of these keywords. Four online databases were employed for the search: Business 
Source Premier, Emerald, Scopus, and Google Scholar. Additionally, the following journals were searched with a view to making 'serendipitous findings' (Callahan, 2014, p. 273):

- $\quad$ Education \& Training

- Entrepreneurship Theory and Practice

- Family Business Review

- Human Resource Development Quarterly

- International Small Business Journal

- Journal of Business Venturing

- Journal of Small Business and Enterprise Development

- Journal of Small Business Management

- Journal of Workplace Learning

- Small Business Economics

- Small Enterprise Research

A total of 15 articles satisfied the inclusion criteria and key aspects of these articles are summarised in Table 1.

Insert Table 1 about here

Each article was carefully reviewed and streams of related ideas were identified in the literature (Torraco, 2016). Four broad themes emerged from our analysis of the literature: (1) distinctive characteristics of small businesses affect informal learning; (2) the external organisational environment can create pressure to learn; (3) owners/managers play a critical role in fostering informal learning through their strategic choices; and (4) the importance of creating conditions that foster informal learning.

First, consistent with the views of numerous commentators on small businesses in general 
(e.g., Josefy et al., 2015; Welsh \& White, 1981), a dominant theme in the reviewed articles was the importance of not treating the small business as a scaled-down version of a large business. Several authors argue that there are fundamental differences between large and small businesses in areas relevant to the study of informal learning (e.g., Anderson \& Boocock, 2002; Billett, Hernon-Tinning \& Ehrich, 2003; Lans, Biemans, Verstegen \& Mulder, 2008). However, although these researchers attempt to integrate this perspective into their studies, there is typically scope for them to pay closer attention to distinctive characteristics of small businesses. Distinctive characteristics that are asserted to negatively affect learning include: resource paucity (Coetzer, 2006b; Coetzer \& Perry, 2008); lack of expertise that is necessary to facilitate emergent learning (Kelliher \& Bernadette Henderson, 2006); undeveloped feedback structures (Birdthistle, 2008); and lack of communication systems necessary for knowledge dissemination (Anderson \& Boocock, 2002). Distinctive characteristics that are purported to positively affect informal learning include: the informal organisational culture (Anderson \& Boocock, 2002); a strong preference for 'learning-by-doing' (Dalley \& Hamilton, 2000); and opportunities to use skills and abilities because of job autonomy and wide task variety (Coetzer, 2006a).

A second theme in the reviewed literature was the importance of the external organisational environment (typically denoted as the 'business environment', 'market environment', or 'competitive environment') in relation to informal learning in small businesses (Coetzer \& Perry, 2008; Kelliher \& Bernadette Henderson, 2006; Lans et al., 2008). From this perspective, some characteristics of the external environment can act as a driving force for learning (e.g. severity of competition), or as learning triggers (e.g. technology developments) (Coetzer \& Perry, 2008). For example, in their longitudinal case study, Kelliher and Henderson (2006) found that pressure from an important commercial partner resulted in the case study organisation adopting a new information system which served as an important catalyst for learning within the case study organisation. Similarly, Lans et al., (2008) found that the extent of interaction with external parties (e.g., consumers, suppliers) had an important influence on 
learning in the small businesses studied.

A third theme is the critical role that owners/managers play in fostering informal learning in small businesses through strategic choices that they make and the resultant emphasis that they place on learning. The owner/manager is an important power-holder in determining the market and/or the entrepreneurial orientation of the small business. Owners/managers who wish to strengthen their firm's market orientation must build the strategic capability of customerconnection within the firm, while an entrepreneurial orientation involves seeking to gain a strategic advantage by supporting entrepreneurial behaviour within the small business (Lans et al., 2008). Moreover, there is a link between the entrepreneurial or market orientation of the business and the willingness of the owner/manager to foster learning in the business (Lans et al., 2008). In brief, the stronger the market and/or entrepreneurial orientation of the business, the stronger the learning orientation of the owner/manager (Chaston, Badger \& Sadler-Smith, 2001).

The fourth and final theme that emerged from our analysis relates to the importance of creating conditions necessary for promoting informal learning in small businesses (e.g., an enabling 'learning environment' or a positive 'learning culture'). The traditional way of promoting learning through providing employees with access to employer-sponsored training (i.e. formal learning) is often criticised as an 'ineffective' approach and an 'inappropriate' way of conceptualising learning in small businesses (Anderson \& Boocock, 2002; Billett et al., 2003). Rather than relying on traditional ways of learning (e.g., attending training courses), small businesses should capitalise on their relative advantages and develop a 'learning framework' congruent with the distinctive characteristics of the small firm (Kelliher \& Bernadette Henderson, 2006). Developing a 'learning framework’ includes initiatives such as: utilising localised learning support (Billett et al., 2003); providing incentives to learn and support for learning (Coetzer, 2006a; Coetzer, 2006b; Ehrich \& Billett, 2004); leveraging the learning potential embedded in everyday work practice, such as team-based learning practices (Ahlgren \& Engel, 2011; Birdthistle, 2008; Coetzer, 2007: McPherson \& Wang, 2014); and expanding the 
learning potential of the work system by increasing the levels of autonomy and skill variety in jobs (Coetzer, 2006a). Within such a 'learning framework', the roles of owners, managers and other potential learning facilitators (e.g., peers, advisers, experts, family members) are viewed as being important in creating conditions that foster learning (Billett et al., 2003; Coetzer, 2006a; Coetzer, 2006b; Dalley \& Hamilton, 2000; Kelliher \& Bernadette Henderson, 2006). However, not all of these actors have the capabilities and willingness to foster the learning of staff. For example, Coetzer (2006a) found that many supervisors do not view fostering employee learning as a priority action, or they lack the required knowledge, skills and personal attributes to effectively perform their role in supporting the learning of staff. Additionally, managers may be more willing to foster the learning of some staff. For instance, Coetzer, Peter and Peter (2011) found that managers devoted most of their attention and resources towards fostering the learning of novices and neglected the learning of more experienced employees. Similarly, McPherson and Wang (2014) found that supervisors were less inclined to support the learning of employees who did not seem to assimilate the business owner's work values and beliefs.

The empirical literature on informal learning in small business businesses that we reviewed has several weaknesses. First, our analysis identified methodological patterns that may negatively affect the quality of research on informal learning in small businesses. The majority of studies were qualitative and the case study method was the predominant method employed in these studies. Just four studies involved collection of quantitative data and only one study combined qualitative and quantitative data. All but one of the studies were cross-sectional. These methodological patterns point to an obvious need for more longitudinal, innovative and research context-specific approaches, such as the approaches recommended by Nolan and Garavan (2016a). Second, most studies did not distinguish between types of learning (e.g., adaptive and innovative learning) and the differing conditions and approaches necessary to foster each type of learning. Furthermore, learning was often inadequately defined and the differences between incidental, informal and formal learning was often difficult to distinguish in the empirical work. 
Third, few studies explicitly link informal learning to outcomes for the organisation or employees. This may be because of the challenges involved in measuring informal learning (Skule, 2004). Finally, of particular significance from the perspective of this paper, the findings largely reflect how characteristics that determine differences among small businesses (i.e. small business heterogeneity) affect informal learning, rather than how characteristics that distinguish small businesses from large businesses (i.e. small business specificity) affect informal learning. In the following sections of the paper we address this final limitation of the existing literature. We do so by integrating literature streams on (1) workplace factors that influence informal learning and (2) distinctive characteristics of small businesses, in such a way that new frameworks and perspectives on the research topic of informal learning in small businesses are generated (Torraco, 2005; 2016).

\section{Workplace Factors Influencing Informal Learning}

It is widely recognised that the workplace environment has a powerful influence on employees' work-related learning (Ellinger, 2005; Maurer, 2002; Skule, 2004). Accordingly, scholars have sought to identify factors in workplace environments that foster or constrain employee learning (e.g., Noe \& Wilk, 1993; Kraimer, Seibert, Wayne, Liden \& Bravo, 2011; Tannenbaum, 1997). Although considerable literature is devoted to identifying such factors, no single approach to categorising these factors dominates the literature. In this paper we categorise these factors as job, relational and organisational characteristics.

Job characteristics: There is wide agreement in the literature that the kinds of work activities individuals engage in can be a primary source of learning for employees (e.g. Billett, 2004; Ellström, 2001; Parker, 2014). Scholars frequently evoke the job characteristics model (JCM) and demand-control model (DCM) to explain how job characteristics affect employee learning (Raemdonck, Gijbels \& van Groen, 2014; Wielenga-Meijer, Taris, Kompier, Wigboldus, 2010). Briefly, the JCM (Hackman \& Oldham, 1975, 1980) describes the relations 
among (a) five core job dimensions, (b) three critical psychological states, and (c) personal as well as work outcomes. According to Hackman and Oldham, jobs that are likely to motivate performance and contribute to employee satisfaction exhibit five core job dimensions to a great degree: skill variety; task identity; task significance; autonomy; and feedback from the job itself. These job dimensions produce three psychological states: experienced meaningfulness; experienced responsibility; and knowledge of results. The three psychological states, in turn, lead to positive personal (e.g., high internal work motivation) as well as work outcomes (e.g., low turnover and absenteeism). The model suggests that increasing the motivational potential of jobs by positively influencing one or more of the five core job dimensions will motivate performance among those employees who value opportunities for learning and growth (Oldham \& Hackman, 2010). That is, employees’ learning and growth needs strengths moderates the relationship between job characteristics and employees’ responses.

The DCM (Karasek, 1979; Karasek \& Theorell, 1990) focuses on the interaction between two dimensions: (a) degree of psychological demands of the job; and (b) degree of decision latitude. Job demands refer to a tasks mental workload and the mental arousal needed to carry out the task. Decision latitude is defined as a combination of an employee's autonomy to make decisions on the job (decision authority) and the breadth of skills used by the employee on the job (skill discretion). Within the DCM, the active learning hypothesis predicts that a combination of high demands and high decision latitude will increase work motivation, learning, and personal growth.

In sum, the job characteristics model and demand-control model suggest that some job characteristics are related to workplace learning. Collectively, these job characteristics are referred to as the 'job resources' which are known to have positive effects on employee wellbeing, including stimulating personal growth, learning and development (Bakker \& Demerouti, 2007). However, the mechanisms that connect these job characteristics to learning consequences are not yet well understood (Raemdonck et al., 2014; Taris \& Kompier, 2005). Wielenga-Meijer 
et al. (2010) identified motivational, cognitive and behavioural processes as potential mediators of the job characteristics-learning consequences relationship. They theorised that job demands, task or skill variety, autonomy and feedback affect learning through motivational (e.g. drive for competence), cognitive (e.g. building a proper mental model) and behavioural (e.g. exploration behaviour) processes. After reviewing 85 empirical studies on relationships among job characteristics, learning processes and learning consequences they concluded that no relationship proposed in their model was disconfirmed. That is, evidence regarding relationships in their model was either absent or consistent with their hypotheses.

Relational characteristics: Several learning theories emphasise that learning is inherently socially constructed and contextually embedded (Ellinger, 2005). For example, social learning theory (Bandura, 1977) suggests that people learn by observing the behaviours or skills of other persons ('models') whom they believe to be credible. Learners must memorise the observed behaviours or skills and try them out in appropriate situations with the expectation that they result in the same positive reinforcement that the model received (Noe, 2017). Similarly, situated learning theory proposes that knowledge and skills are developed and made meaningful by the context in which they are acquired and that situated learning emanates from performing authentic work activities guided by expert practitioners situated in a culture of practice (Lave \& Wenger, 1991). Consistent with tenets of these theories, research on workplace learning shows that the majority of employees' learning occurs informally in the workplace itself and that learning from the other people with whom they work is a primary mode of learning (Eraut, 2007; Tannenbaum, 1997).

Learning from other people in the workplace is likely to flourish within the context of good social relationships (Ellinger, 2005; Eraut, 2007). Characteristics of the interpersonal relationships that employees have in the workplace are likely to affect their learning behaviours. For example, findings of social networks research that examines help seeking, information seeking, and feedback seeking behaviours in the workplace suggest that work environments in 
which employees trust and respect each other will help to foster such learning behaviours (e.g. Borgatti \& Cross, 2003; van der Rijt, Van den Bossche, van de Wiel, De Maeyer, Gijselaers \& Segers, 2013). As Borgatti and Cross (2003), note, there are 'costs’ involved in asking others for assistance, such as admitting ignorance on a topic and incurring obligations due to norms of reciprocity. Thus, employees are more likely to seek information, feedback, and help with problem-solving in social environments characterised by trust, respect and accessibility to those with relevant expertise (van der Rijt et al., 2013).

Internal organisational characteristics: Studies have identified several organisational contextual factors that foster or constrain informal learning at work. For example, Ellinger (2005) used case study research to explore organisational contextual factors that may influence employees’ informal learning. In her study, factors that positively influenced informal learning included learning-committed leadership and management, and an internal culture committed to learning. Similarly, Skule (2004) analysed telephone survey data collected from 1500 participants to identify organisational contextual factors that foster informal learning at work. The analyses suggested that rewards for proficiency (e.g., higher wages, allocation of more interesting tasks, improved career opportunities) and exposure to demands from important actors (e.g., customers, managers, colleagues) are just some of the many factors that foster informal learning. Findings of these and other studies (e.g., Ashton, 2004; Ellström, Ekholm \& Ellström, 2008; Fuller, Unwin, Felstead, Jewson \& Kakavelakis, 2007; Sambrook, 2005; Watkins \& Cervero, 2000) suggest that there are multiple organisational contextual factors that foster or constrain informal learning at work.

\section{The Three Categories of Factors in the Small Business Context}

In this section of the paper we examine each of the three categories of factors that influence informal learning in the context of small business. This is done through integrating primarily literatures which examine (1) workplace factors that influence informal learning and (2) small 
business characteristics. Drawing on mainly these two literature streams, we develop a set of research propositions that should be examined in future research. These propositions are summarised in Table 2.

\section{Insert Table 2 about here}

Job characteristics: There is a persistent view in the literature that employees in many small businesses have broad, discretionary roles and therefore high task or skill variety (Kalleberg \& Van Buren, 1996; Wallace \& Kay, 2009). This may stem from small businesses being more informal workplaces with fewer documented HRM policies and procedures (e.g. job descriptions) than their larger counterparts (Storey, Saridakis, Sen-Gupta, Edwards \& Blackburn, 2010). Furthermore, managers and non-managerial employees are expected to be multi-skilled, because small businesses rely on fewer personnel for multiple activities (Ghobadian \& Gallear, 1997). There is also a strong theme in the literature that employees in small businesses tend to experience high levels of job autonomy (Kalleberg \& Van Buren, 1996; Wallace \& Kay, 2009). For example, Forth, Bewley and Bryson (2006) found that small business employees were more likely to believe that they had job autonomy than employees in larger businesses. In their study, small business employees also rated managers more highly than employees in large businesses in the extent to which they sought employees' views, responded to employees' suggestions, and allowed employees to influence final decisions. Arguably, employees in small businesses also experience high levels of task significance, because they can more readily see how their jobs affect the organisation (Ghobadian \& Gallear, 1997). These intrinsically rewarding characteristics of jobs in small businesses (i.e. high task or skill variety, wide scope for action, and task significance) should enhance the learning potential of jobs (Oldham \& Hackman, 2010). 
In accordance with the above arguments, we propose the following: Proposition 1: In small businesses, informal learning is enhanced by learning embedded in everyday goal-directed work activities, which tend to be characterised by high task or skill variety, wide scope for action, and task significance.

Relational characteristics: Literature suggests that there are distinctive relational characteristics of social environments in small businesses which have potentially important implications for informal learning. In small businesses, both the informal recruitment practices (Williamson, 2000) and the social and spatial proximity of small workplaces (Marlow, Taylor \& Thompson, 2010), potentially contribute to forging strong ties among employees. Such strong ties could, in turn, have positive effects on informal learning. In many small businesses, recruitment of employees is done informally, with employee referral or 'word-of-mouth' a preferred recruitment method (Cardon \& Stevens, 2004; Williamson, 2000). This method typically involves managers asking staff to help locate prospective employees. When such an approach is used, it is more likely that newcomers will be from the current employees' familial and social milieu. Consistent with the similarity-attraction effect (Byrne et al., 1971), people employed in small businesses through the employee referral method are likely to share personal characteristics of those who recommend them. As a consequence, work groups in small businesses may tend to be homogenous. Compared to diverse groups, members of homogenous groups experience better interpersonal relations, less relationship conflict and higher satisfaction (Thatcher \& Patel, 2012). Furthermore, work groups also tend to be more cohesive when their members have regular, face-to-face interaction (Friedkin, 2004). This type of interaction is more likely to occur among group members when they work in the same physical space, as in small business settings which are characterised by social and spatial proximity (Marlow et al., 2010). On the other hand, the tendency to employ family and friends may have dampening effects on intragroup constructive (positive) conflict which, in turn, could inhibit innovative learning (Jehn \& Bendersky, 2003). 
There is also a view that small business managers have relatively better prospects of cultivating positive employee relations and egalitarian cultures, primarily because of the managerial informality that characterises small businesses (Storey et al., 2010) and the regular and personalised communication that can occur between employer and employees (Tsai, SenGupta \& Edwards, 2007). Consistent with this view, a study of employment practices in SMEs and larger firms by Forth et al. (2006) found that levels of trust between managers and employees and rating of management-employee relations were highest in small businesses. Similarly, Tsai et al.’s (2007) results relating to attitudes to managers suggest that employees in small businesses have the closest, and the most satisfactory, relationships with managers. Through frequent and close contact with staff, employers can share their vision for the business, which should facilitate alignment of employee learning with strategic priorities of the small business. Thus, overall, small businesses seem to offer an array of relational benefits, such as close and satisfying working relationships with co-workers and owner-managers, and a 'familial' environment, that are difficult to replicate in large organisations (Saridakis, Torres \& Johnstone, 2013; Tsai et al., 2007). The socially and intrinsically rewarding nature of work in small businesses may help to explain why small business employees typically report higher levels of job satisfaction (e.g., Idson, 1990) and self-reported job quality (e.g., Storey et al., 2010).

Consistent with the foregoing arguments, we propose the following: Proposition 2: In small businesses, informal learning is enhanced through the (a) tendency to involve family and friends as workers; (b) spatial and social proximity of employees; and (c) personal and frequent employer-employee interaction. Proposition 3: In small businesses, innovative learning is potentially inhibited by family labour and the formation of homogenous work groups which tend to evolve because owner-managers employ informal recruitment practices.

Organisational characteristics: As noted, literature suggests that there are a multitude of organisational contextual factors that foster or constrain informal learning at work However, 
here we focus on just two organisational contextual factors that are specific to small businesses in general and which potentially influence informal learning in these settings.

The structure of the organisation is a factor within the internal organisational environment that can have significant impacts on the quantity and quality of informal learning (Ashton, 2004; Ellinger, 2005). The nature of organisational structure is interconnected with firm size. As outlined in Josefy et al. (2015), large firms tend to have relatively tall, functional structures of the mechanistic type. They are generally more bureaucratic and reliant on formalisation to standardise employee behaviour through policies, procedures, rules and related mechanisms. Small firms, on the other hand, tend to have flat, simple structures of the organic type. In general, they have attributes of adhocracy (as opposed to bureaucracy), such as flexible, adaptable structures and informal working relationships. Organic structures are more conducive to informal learning, than structures that are mechanistic, because mechanistic structures can produce hierarchical and functional barriers that act as 'walls' to knowledge sharing within organisations (Ellinger \& Cseh, 2007; Kuan \& Aspinwall, 2004). Small businesses are characterised by the absence of a departmental or functional 'mindset', which is more likely to prevail in large organisations (Ghobadian \& Gallear, 1997). On the other hand, informal learning may be negatively affected by limited opportunities for career development due to absence of internal labour markets in small businesses (Wallace \& Kay, 2009).

Large businesses are likely to have more internal resources at their disposal, including access to learning and development specialists, such as a Chief Learning Officer (Strange, 2012). Managers who wish to foster the learning of staff should ideally have access to such specialists who can provide them with practical advice and behavioural guidelines that will help managers enhance informal learning at work. Promoting informal learning is complicated and requires knowledge of the wide array of individual and workplace factors that potentially influence the effectiveness of informal learning (Tannenbaum et al., 2010). Small businesses rarely have designated human resource personnel to provide guidance on matters relating to people 
management practices in general, and employee learning in particular (Cardon \& Stevens, 2004). Furthermore, fostering employee learning may receive less managerial attention in small businesses, because owner/managers typically perform a variety of day-to-day functions that are delegated to others in large businesses (Chadwick, Way, Kerr \& Thacker, 2013; Florén, 2006). Managerial attention is a critical organisational resource that is markedly constrained in small businesses (Chadwick et al., 2013).

In accordance with the foregoing arguments, we propose the following. Proposition 4: In small businesses, informal learning is constrained by lack of: (a) managerial attention to promoting informal learning; (b) specialised knowledge and skills required to foster informal learning; and (c) internal labour markets. Proposition 5: In small businesses, organic structures and adhocracy are facilitative of informal learning.

There are undoubtedly several other propositions relating to factors that influence informal learning in small businesses that researchers may wish to test. For these researchers we have developed a heuristic conceptual framework (Table 3) which can help to focus and bound their research. The framework was generated through integrating the theoretical and empirical works of authors referenced previously.

Insert Table 3 about here

\section{Limitations}

The foregoing review is limited by its scope. First, we by no means argue that we have identified all relevant small business characteristics, nor that we have fully explored the potential effects of each characteristic on informal learning. Second, we have not examined potential effects on informal learning of external environmental factors specific to small businesses (e.g. government-backed initiatives to promote learning in small businesses). Third, while we recognise the heterogeneity of small businesses, our review did not consider factors that determine differences among small businesses, such as the industry sector. For example, small 
businesses that provide knowledge intensive services are likely to employ more formal models of human resource management compared to small businesses that provide standardised and simple services (Boxall \& Purcell, 2016). Finally, as noted, personal characteristics (e.g. feedback-seeking orientation) also influence informal learning, but were excluded from the review. Arguably, personal characteristics are peripheral to advancing knowledge on factors that influence informal learning in small businesses.

\section{Conclusion}

Despite the numerical and economic significance of small businesses in developed economies and their strong preference towards informal learning processes, few studies have examined workplace factors that influence informal learning in small businesses. Furthermore, these studies are typically not framed within the context of distinctive characteristics of small businesses. Thus, small business characteristics are insufficiently accounted for in findings of the small body of existing research. We contend that a lack of careful attention to the specific nature of small businesses in studies which examine informal learning processes will impede the progress of this important research stream.

Numerous interesting opportunities for future research exist within this research stream, just some of which are enunciated by our propositions. Other interesting lines of inquiry include comparative studies that examine how job, relational and organisational characteristics affect informal learning in small businesses located in different national contexts. Similarly, comparative studies of the effects of job, relational and organisational characteristics on informal learning in micro, small and medium-sized enterprises would be a potentially fruitful line of inquiry. Given the key role that owners/managers can enact in creating conditions that are favourable to informal learning, research which investigates how owners/managers should leverage job, relational and organisational characteristics to enhance informal learning could contribute to an understanding of learning-oriented leadership in small business contexts. We 
hope that researchers will be stimulated to pursue the propositions set forth in this paper and other interesting lines of inquiry to advance our collective knowledge on informal learning in small businesses and that they will also heed our call to pay careful attention to distinctive characteristics of small businesses when designing their studies. 


\section{References}

Ahlgren, L., \& Engel, L. C. (2011). Lifelong learning through SMEs: exploring workplace learning in the UK. Journal of Workplace Learning, 23(5), 331-348.

Anderson, V., \& Boocock, G. (2002). Small firms and internationalisation: learning to manage and managing to learn. Human Resource Management Journal, 12(3), 5-24.

Aguinis, H., \& Kraiger, K. (2009). Benefits of training and development for individuals and teams, organizations, and society. Annual Review of Psychology, 60, 451-474.

Ashton, D. N. (2004). The impact of organizational structure and practices on learning in the workplace. International Journal of Training and Development, 8(1), 43-53.

Bakker, A. B., \& Demerouti, E. (2007). The job demands-resources model: State of the art. Journal of Managerial Psychology, 22(3), 309-328.

Bandura, A. (1977). Social learning theory. Englewood Cliffs, NJ: Prentice-Hall.

Billett, S. (2004). Workplace participatory practices: Conceptualising workplaces as learning environments. Journal of Workplace Learning, 16(6), 312-324.

Billett, S., Hernon-Tinning, B., \& Ehrich, L. (2003). Small business pedagogic practices. Journal of Vocational Education and Training, 55(2), 149-167.

Birdthistle, N. (2008). Family SMEs in Ireland as learning organizations. The Learning Organization, 15(5), 421-436.

Bolton, J. E. (1971). Small firms: Report of the commission of inquiry on small firms. London, Her Majesty’s Stationary Office.

Borgatti, S. P., \& Cross, R. (2003). A relational view of information seeking and learning in social networks. Management Science, 49(4), 432-445.

Boxall, P. \& Purcell, J. (2016). Strategic human resource management ( $^{\text {th }}$ ed.). London: Palgrave MacMillan. 
Burns, J. Z., Schaefer, K., \& Hayden, J. M. (2005). New trade and industrial teachers' perceptions of formal learning versus informal learning and teaching proficiency. Journal of Industrial Teacher Education, 12(3), 66-87.

Burrows, R., \& Curran, J. (1989). Sociological research on service sector small businesses: some conceptual considerations. Work, Employment \& Society, 3(4), 527-539.

Byrne, D., Gouaux, C., Griffitt, W., Lamberth, J., Murakawa, N., Prasad, M., Prasad, A., \& Ramirez, M. (1971). The ubiquitous relationship: Attitude similarity and attraction: A cross-cultural study. Human Relations, 24(3), 201-207

Callahan, J. L. (2010). Constructing a manuscript: Distinguishing integrative literature reviews and conceptual and theory articles. Human Resource Development Review, 9(3), 300304.

Callahan, J. L. (2014). Writing literature reviews: A reprise and update. Human resource Development Review, 13(3), 271-275.

Callanan, M., Cervantes, C., \& Loomis, M. (2011). Informal learning. Wiley Interdisciplinary Reviews: Cognitive Science, 2(6) 646-655.

Cardon, M. S., \& Stevens, C. E. (2004). Managing human resources in small organizations: What do we know? Human Resource Management Review, 14(3), 295-323.

Chadwick. C., Way, S. A., Kerr, G., \& Thacker, J. W. (2013). Boundary conditions of the highinvestment human resource systems-small-firm labour productivity relationship, Personnel Psychology, 66, 311-343.

Chaston, I., Badger, B., \& Sadler-Smith, E. (2001). Organizational learning: An empirical assessment of process in small UK manufacturing firms. Journal of Small Business Management, 39(2), 139-151.

Choi, W., \& Jacobs, R. L. (2011). Influences of formal learning, personal learning orientation, and supportive learning environment on informal learning. Human Resource Development Quarterly, 22(3), 239-257. 
Coetzer, A. (2006a). Employee learning in New Zealand small manufacturing firms. Employee Relations, 28(4), 311-325.

Coetzer, A. (2006b). Managers as learning facilitators in small manufacturing firms. Journal of Small Business and Enterprise Development, 13(3), 351-362.

Coetzer, A. (2007). Employee perceptions of their workplaces as learning environments. Journal of Workplace Learning, 19(7), 417-434.

Coetzer, A., \& Perry, M. (2008). Factors influencing employee learning in small businesses. Education+ Training, 50(8/9), 648-660.

Coetzer, A., Peter, R., \& Peter, V. (2011). Employee learning processes in New Zealand small manufacturing firms. Journal of Management \& Organization, 17(06), 764-781.

Curran, J., \& Blackburn, R. A. (2001). Older people and the enterprise society: Age and selfemployment propensities. Work, Employment \& Society, 15(04), 889-902.

d'Amboise, G., \& Muldowney, M. (1988). Management theory for small business: Attempts and requirements. Academy of Management Review, 13(2), 226-240.

Dalley, J., \& Hamilton, B. (2000). Knowledge, context and learning in the small business. International Small Business Journal, 18(3), 51-51.

De Winne, S., \& Sels, L. (2012). Progress and prospects for HRM-performance research in small and medium-sized businesses. In D.E. Guest, J. Paauwe \& P. Wright (Eds.), HRM and performance: Achievements and challenges (pp. 173-196). Hoboken: Wiley.

Devins, D., Johnson, S., \& Sutherland, J. (2004). Employer characteristics and employee training outcomes in UK SMEs: A multivariate analysis. Journal of Small Business and Enterprise Development, 11(4), 449-457.

Ehrich, L. C. \& Billett, S. (2004). Learning new practices in small business: Engagement and localised support. Education+ Training, 46(8/9), 501-509. 
Ellinger, A. D. (2005). Contextual factors influencing informal learning in a workplace setting: The case of "Reinventing Itself Company”. Human Resource Development Quarterly, 16(3), 389-415.

Ellinger, A. D., \& Cseh, M. (2007). Contextual factors influencing the facilitation of others' learning through everyday work experiences. Journal of Workplace Learning, 19(7), 435-452.

Ellström, P. E. (2001). Integrating learning and work: Problems and prospects. Human Resource Development Quarterly, 12(4), 421-435.

Ellström, P. E. (2010). Practice-based innovation: A learning perspective. Journal of Workplace Learning, 22(1), 27-40.

Ellström, E., Ekholm, B., \& Ellström, P. E. (2008). Two types of learning environment: Enabling and constraining a study of care work. Journal of Workplace Learning, 20(2), 84-97.

Eraut, M. (2000). Non-formal learning and tacit knowledge in professional work. British Journal of Educational Psychology, 70(1), 113.

Eraut, M. (2007). Learning from other people in the workplace. Oxford Review of Education, 33(4), 403-422.

Fenwick, T. (2003). Innovation: examining workplace learning in new enterprises. Journal of Workplace Learning, 15(3), 123-132.

Forth, J., Bewley, H., \& Bryson, A. (2006). Small and Medium-Sized Enterprises: Findings from the 2004 Workplace Employment Relations Survey, London: Department of Trade and Industry; Economic and Social Research Council.

Florén, H. (2006). Managerial work in small firms: Summarising what we know and sketching a research agenda. International Journal of Entrepreneurial Behaviour \& Research, 12(5), 272-288.

Florén, H., \& Tell, J. (2003). Key learning themes in the small business literature. Small Enterprise Research, 11(1), 56-70. 
Fuller, A., Unwin, L., Felstead, A., Jewson, N., \& Kakavelakis, K. (2007). Creating and using knowledge: an analysis of the differentiated nature of workplace learning environments. British Educational Research Journal, 33(5), 743-759.

Friedkin, N. E. (2004). Social cohesion. Annual Review of Sociology, 30, 409-425.

Ghobadian, A., \& Gallear, D. (1997). TQM and organisation size. International Journal of Operations \& Production Management, 17(2), 121-163.

Hackman, J. R., \& Oldham, G. R. (1975). Development of the job diagnostic survey. Journal of Applied Psychology, 60, 159-170.

Hackman, J. R., \& Oldham, G. R. (1980). Work redesign. Reading. MA: Addison-Wesley.

Hughes, C. (2004). The supervisor's influence on workplace learning. Studies in Continuing Education, 26(2), 275-287.

Idson, T. (1990). Establishment size, job satisfaction and the structure of work. Applied Economics, 22(8), 606-628.

Jehn, K. A., \& Bendersky, C. (2003). Intragroup conflict in organizations: A contingency perspective on the conflict-outcome relationship. Research in Organizational Behaviour, $25,187-242$.

Josefy, M., Kuban, S., Duane Ireland, R., \& Hitt, M. A. (2015). All things great and small: Organizational size, boundaries of the firm, and a changing environment. The Academy of Management Annals, 9(1), 715-802.

Kalleberg, A. L., \& Van Buren, M. E. (1996). Is big better? Explaining the relationship between organization size and job rewards. American Sociological Review, 61, 47-66.

Karasek, R. A., \& Theorell, T. (1990). Healthy work: stress, productivity, and the reconstruction of working life. New York: Basic Books.

Karasek, R. A. (1979). Job demands, job decision latitude and mental strain: Implications for job design. Administrative Science Quarterly, 24, 285-308. 
Kelliher, F., \& Bernadette Henderson, J. (2006). A learning framework for the small business environment. Journal of European Industrial Training, 30(7), 512-528.

Kitching, J. (2007). Regulating employment relations through workplace learning: a study of small employers. Human Resource Management Journal, 17(1), 42-57.

Kotey, B., \& Folker, C. (2007). Employee training in SMEs: Effect of size and firm type - family and nonfamily. Journal of Small Business Management, 45(2), 214-238.

Kraimer, M. L., Seibert, S. E., Wayne, S. J., Liden, R. C., \& Bravo, J. (2011). Antecedents and outcomes of organizational support for development: The Critical Role of Career Opportunities. Journal of Applied Psychology, 96(3), 485-500.

Kuan, Y. W., \& Aspinwall, E. (2004). Characterizing knowledge management in the small business environment. Journal of Knowledge Management, 8(3), 44-61.

Kyndt, E., \& Baert, H. (2013). Antecedents of employees’ involvement in work-related learning: A systematic review. Review of Educational Research, 83(2), 273-313.

Lans, T., Biemans, H., Verstegen, J., \& Mulder, M. (2008). The influence of the work environment on entrepreneurial learning of small-business owners. Management Learning, 39(5), 597-613.

Lave, J., \& Wenger, E. (1991). Situated learning: Legitimate peripheral participation. Cambridge, England: Cambridge University Press.

Manuti, A., Pastore, S., Scardigno, A. F., Giancaspro, M. L., \& Morciano, D. (2015). Formal and informal learning in the workplace: A research review. International Journal of Training and Development, 19(1), 1-17.

Marlow, S., Taylor, S., \& Thompson, A. (2010). Informality and formality in medium-sized companies: Contestation and synchronization. British Journal of Management, 21(4), 954-966.

Marsick, V. J., \& Watkins, K. E. (1990). Informal and incidental learning in the workplace. London: Routledge. 
Maurer, T. J. (2002). Employee learning and development orientation: Toward an integrative model of involvement in continuous learning. Human Resource Development Review, 1(1), 19-44.

McPherson, R., \& Wang, J. (2014). Low-income low-qualified employees’ access to workplace learning. Journal of Workplace Learning, 26(6/7), 462-473.

Muller, P. Caliandro, C., Peycheva, V. Gagliardi, D. Marzocchi, C. Ramlogan, R. \& Cox, D. (2015). Annual Report on European SMEs 2014/2015. Brussels: European Commission.

Noe, R.A. (2017). Employee training \& development ( ${ }^{\text {th }}$ ed.). New York: McGraw-Hill Education.

Noe, R. A., Clarke, A. D. M., \& Klein, H. J. (2014). Learning in the twenty-first-century workplace. Annual Review of Organizational Psychology and Organizational Behaviour, $1,245-275$.

Noe, R. A., Tews, M. J., \& Marand, A. D. (2103). Individual differences and informal learning in the workplace. Journal of Vocational Behaviour, 83(3), 327-335.

Noe, R. A., \& Wilk, S. L. (1993). Investigation of the factors that influence employee's participation in development activities. Journal of Applied Psychology, 78(2), 291-302.

Nolan, C. T., \& Garavan, T. N. (2016a). Human resource development in SMEs: A systematic review of the literature. International Journal of Management Reviews, 18(1), 85-107.

Nolan, C. T., \& Garavan, T. N. (2016b). Problematizing HRD in SMEs: A “Critical” Exploration of Context, Informality, and Empirical Realities. Human Resource Development Quarterly, 27(3), 407-442.

Oldham, G. R., \& Hackman, J. R. (2010). Not what it was and not what it will be: The future of job design research. Journal of Organizational Behavior, 31(2-3), 463-479.

Olsen, D. S. (2016). Adult Learning in innovative organisations. European Journal of Education, 51(2), 210-226. 
Paolillio, J. G. P. (1984). The manager's self-assessment of managerial roles: Small vs. large firms. American Journal of Small Business, 8(3), 58-64.

Parker, S. K. (2014). Beyond motivation: Job and work design for development, health, ambidexterity, and more. Annual Review of Psychology, 65, 661-691.

Penrose, E. T. (1959). The theory of the growth of the firm. Oxford, England: Blackwell.

Raemdonck, I., Gijbels, D., \& van Groen, W. (2014). The influence of job characteristics and self-directed learning orientation on workplace learning. International Journal of Training and Development, 18(3), 188-203.

Saridakis, G., Muñoz Torres, R., \& Johnstone, S. (2013). Do human resource practices enhance organizational commitment in SMEs with low employee satisfaction? British Journal of Management, 24(3), 445-448.

Sambrook, S. (2005). Factors influencing the context and process of work-related learning: Synthesizing findings from two research projects. Human Resource Development International, 8(1), 101-119.

Skule, S. (2004). Learning conditions at work: A framework to understand and assess informal learning in the workplace. International Journal of Training and Development, 8(1), 817.

Strange, W. (2012). Interview with Andrew Kilshaw, Chief Learning Officer at Nike Inc. Development and Learning in Organizations, 26(3), 32-34.

Storey, D. J. (1994). Understanding the small business sector. University of Illinois at UrbanaChampaign's Academy for Entrepreneurial Leadership Historical Research Reference in Entrepreneurship.

Storey, D. J., Saridakis, G., Sen-Gupta, S., Edwards, P. K., \& Blackburn, R. A. (2010). Linking HR formality with employee job quality: The role of firm and workplace size. Human Resource Management, 49(2), 305-329. 
Tannenbaum, S. I., Beard, R. L., McNall, L. A., \& Salas, E. (2010). Informal learning and development in oragnizations. In S. W. J. Kozlowski \& E. Salas. Learning, training and development in organizations (pp. 303-331). London: Taylor and Francis.

Tannenbaum, S. I. (1997). Enhancing continuous learning: Diagnostic findings from multiple companies. Human Resource Management, 36(4), 437-452.

Taris, T. W., \& Kompier, M. A. J. (2005). Job characteristics and learning behaviour. In P. L. Perrewe' \& D. C. Ganster (Eds.), Research in occupational stress and well-being: Exploring interpersonal dynamics (pp. 127-166). Amsterdam: JAI Press.

Thatcher, S. M. B. \& Patel, P. C. (2012). Group fault lines: A review, integration, and guide to future research. Journal of Management, 38(4), 969-1009

Torraco, R. J. (2005). Writing integrative literature reviews: Guidelines and examples. Human Resource Development Review, 4(3), 356-367.

Torraco, R.J. (2016). Writing integrative literature reviews: Using the past and present to explore the future. Human Resource Development Review, 15(4), 404-428.

Tsai, C. J., Sengupta, S., \& Edwards, P. (2007). When and why is small beautiful? The experience of work in the small firm. Human Relations, 60(12), 1779-1808.

van der Rijt, J., Van den Bossche, P., van de Wiel, M.W.J., De Maeyer, S., Gijselaers, W. H., \& Segers, M.S.R. (2013). Asking for help: A relational perspective on help seeking in the workplace. Vocations and Learning, 6, 259-279.

Wallace, J. E., \& Kay, F. M. (2009). Are small firms more beautiful or is bigger better? A study of compensating differentials and law firm internal labour markets. The Sociological Quarterly, 50, 474-496.

Warhurst, R. P. (2013). Learning in an age of cuts: Managers as enablers of workplace learning. Journal of Workplace Learning, 25(1), 37-57.

Watkins, K. E., \& Cervero, R. M. (2000). Organizations as contexts for learning: A case study in certified public accountancy. Journal of Workplace Learning, 12(3), 187-194. 
Watkins, K. E., \& Marsick, V. J. (1992). Towards a theory of informal and incidental learning in organisations. International Journal of Lifelong Education, 11(4), 287-300.

Welsh, J. A., \& White, J. F. (1981). A small business is not a little big business. Harvard Business Review, 59(4), 18-32.

Wielenga-Meijer, E. G. A., Taris, T.W., Kompier, M. A. J., \& Wigboldus, D. H. J. (2010). From task characteristics to learning: A systematic review. Scandinavian Journal of Psychology, 51(5), 363-375.

Williamson, I. O. (2000). Employer legitimacy and recruitment success in small businesses. Entrepreneurship Theory and Practice, 25(1), 27-42.

\section{Author Biographies}

Alan Coetzer ( $\mathrm{PhD}$, Massey University) is a senior lecturer in strategic human resource management in the School of Business and Law at Edith Cowan University, Western Australia. His research interests include HRM in small and medium-sized enterprises with a special focus on employee learning and development.

Henrik Kock (PhD, Linköping University) is an associate professor in the Department of Behavioural Sciences and Learning at Linköping University, Sweden. He is also affiliated with the HELIX Competence Centre at the same university. His research interests include learning and competence development, workplace learning, leadership and organisational renewal.

Andreas Wallo (PhD, Linköping University) is a senior lecturer in the Department of Behavioural Sciences and Learning at Linköping University, Sweden. He is also affiliated with the HELIX Competence Centre at the same university. His research interests include leadership 
and managerial work in organizations, workplace learning, human resource development, human resource management, and interactive research. 


\section{Table 1:}

\section{Prior studies of informal learning in small business.}

\begin{tabular}{|c|c|c|c|c|}
\hline Literature source & Topics addressed & Purpose of the study & Research design & Main findings \\
\hline $\begin{array}{l}\text { Ahlgren \& Engel } \\
\text { (2011) }\end{array}$ & $\begin{array}{l}\text { Lifelong learning } \\
\text { through SMEs }\end{array}$ & $\begin{array}{l}\text { Examine the role of SMEs in } \\
\text { promoting and/or hindering } \\
\text { educational opportunities to adult } \\
\text { employees in the UK }\end{array}$ & $\begin{array}{l}\text { Case studies of six small firms } \\
\text { and six medium firms. Document } \\
\text { studies and interviews with } \\
\text { owner-managers, managers, HR } \\
\text { managers, and employees. }\end{array}$ & $\begin{array}{l}\text { Multiple forms of training were offered, with an emphasis } \\
\text { on informal and non-formal training as it was considered } \\
\text { more related to the skills needs of the firm. A factor } \\
\text { highlighted as conducive of informal learning and sharing } \\
\text { of knowledge was the office layout in one of the firms. }\end{array}$ \\
\hline $\begin{array}{l}\text { Anderson \& Boocock } \\
\text { (2002) }\end{array}$ & $\begin{array}{l}\text { Learning in small firms } \\
\text { that internationalise }\end{array}$ & $\begin{array}{l}\text { Explore the nature of, and influences } \\
\text { on, learning in small organisations. }\end{array}$ & $\begin{array}{l}\text { Case studies of six small firms. } \\
\text { Interviews with MDs and owners. } \\
\text { Survey data from } 252 \text { firms. } 132 \\
\text { of them had fewer than } 50 \text { staff. }\end{array}$ & $\begin{array}{l}\text { The large firm model of learning is inappropriate; the } \\
\text { distinctive culture and communication systems of small } \\
\text { firms require different approaches to acquisition, } \\
\text { transmission and interpretation of knowledge. }\end{array}$ \\
\hline $\begin{array}{l}\text { Billett, Hernon- } \\
\text { Tinning \& Ehrich } \\
\text { (2003) }\end{array}$ & $\begin{array}{l}\text { Small business } \\
\text { pedagogic practices }\end{array}$ & $\begin{array}{l}\text { Report and discuss the findings of a } \\
\text { study of how } 30 \text { Australian small } \\
\text { businesses learnt to implement a new } \\
\text { practice. }\end{array}$ & $\begin{array}{l}\text { Case studies based on interviews } \\
\text { with } 30 \text { small business operators. }\end{array}$ & $\begin{array}{l}\text { The process of learning comprised movement from an } \\
\text { initial reliance upon external contributions to a greater } \\
\text { independence in practice premised on capacities residing } \\
\text { within the small business. The key a contributions were } \\
\text { those provided by localised support and expertise. } \\
\text { Localised support was potent when it assisted in identifying } \\
\text { the goals for learning and the development of capacities to } \\
\text { operate independently, as well as supporting and } \\
\text { monitoring the progress with the innovation. }\end{array}$ \\
\hline
\end{tabular}




\begin{tabular}{|c|c|c|c|c|}
\hline Birdthistle (2008) & $\begin{array}{l}\text { Family SMEs as } \\
\text { learning organisations }\end{array}$ & $\begin{array}{l}\text { Investigate whether small and } \\
\text { medium-sized family } \\
\text { businesses in Ireland can be classified } \\
\text { as learning organisations }\end{array}$ & $\begin{array}{l}\text { Case studies of two micro, two } \\
\text { small and two medium firms. } \\
\text { Interviews with owner-managers. }\end{array}$ & $\begin{array}{l}\text { Small family businesses have the potential to be classified } \\
\text { as learning organisations. This is due to the fact that small } \\
\text { family businesses have learning at the core of their business } \\
\text { and systems in place to deal with a learning orientation. }\end{array}$ \\
\hline $\begin{array}{l}\text { Chaston, Badger \& } \\
\text { Sadler-Smith (2001) }\end{array}$ & $\begin{array}{l}\text { Organisational learning } \\
\text { in small manufacturing } \\
\text { firms. }\end{array}$ & $\begin{array}{l}\text { Ascertain whether entrepreneurial } \\
\text { firms use higher-order (or double- } \\
\text { loop) learning. Assessing whether } \\
\text { organisational learning confers } \\
\text { information management advantages } \\
\text { and contributes to the upgrading of } \\
\text { managerial competencies. }\end{array}$ & $\begin{array}{l}\text { Survey data from } 179 \text { managing } \\
\text { directors in small firms. }\end{array}$ & $\begin{array}{l}\text { Entrepreneurial firms utilize higher-order learning and are } \\
\text { able to manage information more effectively than non- } \\
\text { entrepreneurial firms. Some evidence supports the view } \\
\text { that higher-order learning influences certain managerial } \\
\text { competencies. }\end{array}$ \\
\hline
\end{tabular}




\begin{tabular}{|c|c|c|c|c|}
\hline Coetzer (2006b) & $\begin{array}{l}\text { Managers as learning } \\
\text { facilitators in small } \\
\text { manufacturing firms. }\end{array}$ & $\begin{array}{l}\text { Describe findings from an exploratory } \\
\text { qualitative study of owner-managers, } \\
\text { managers, and employees in small } \\
\text { manufacturing firms in the } \\
\text { Wellington region. }\end{array}$ & $\begin{array}{l}\text { Interviews with } 17 \text { participants } \\
\text { who were owner-managers, } \\
\text { managers, or employees in } 10 \\
\text { small firms. }\end{array}$ & $\begin{array}{l}\text { Managers promoted learning by: providing access to a } \\
\text { range of workplace activities; promoting communication in } \\
\text { the workplace; facilitating access to direct guidance from } \\
\text { workplace models; and designating learning facilitators. } \\
\text { Informal employee practices used by managers had } \\
\text { unintended positive "side effects” on informal learning. }\end{array}$ \\
\hline Coetzer (2007) & $\begin{array}{l}\text { Employee perceptions } \\
\text { of workplaces as } \\
\text { learning environments }\end{array}$ & $\begin{array}{l}\text { Contribute to an understanding of } \\
\text { how diverse groups of employees } \\
\text { perceive their workplaces as learning } \\
\text { environments, and to cast light on the } \\
\text { learning processes of these diverse } \\
\text { groups of employees. }\end{array}$ & $\begin{array}{l}\text { Survey data from } 464 \text { non- } \\
\text { manager employees and managers } \\
\text { in } 31 \text { small firms. }\end{array}$ & $\begin{array}{l}\text { Results for six demographic groups are presented to } \\
\text { provide a comparative view of employee perceptions. The } \\
\text { two comparison groups within three demographic variables } \\
\text { (tenure, age, education) differed markedly in how they } \\
\text { perceived their workplaces as learning environments. } \\
\text { However, the comparison groups agreed that workmates } \\
\text { and observational processes were central to learning. }\end{array}$ \\
\hline $\begin{array}{l}\text { Coetzer \& Perry } \\
(2008)\end{array}$ & $\begin{array}{l}\text { Factors influencing } \\
\text { employee learning in } \\
\text { small businesses }\end{array}$ & $\begin{array}{l}\text { Identify key factors influencing } \\
\text { employee learning from the } \\
\text { perspective of owners/managers. }\end{array}$ & $\begin{array}{l}\text { Site visits and interviews with the } \\
\text { owners/managers of } 27 \text { small } \\
\text { firms. }\end{array}$ & $\begin{array}{l}\text { Four main themes of factors influencing employee learning } \\
\text { were identified: factors in the external business } \\
\text { environment; factors in the work environment; learning } \\
\text { potential of the job itself; and learning orientations of } \\
\text { employees. }\end{array}$ \\
\hline
\end{tabular}




\begin{tabular}{|c|c|c|c|c|}
\hline $\begin{array}{l}\text { Coetzer, Peter \& Peter } \\
\text { (2011) }\end{array}$ & $\begin{array}{l}\text { Employee learning } \\
\text { processes in small } \\
\text { manufacturing firms }\end{array}$ & $\begin{array}{l}\text { Examine the potentially differing } \\
\text { learning processes of novices and } \\
\text { experienced specialists. }\end{array}$ & $\begin{array}{l}\text { Survey data collected from } 76 \\
\text { novices and } 142 \text { experienced } \\
\text { specialists in } 31 \text { small firms. }\end{array}$ & $\begin{array}{l}\text { Novices and experienced specialists differ in their } \\
\text { perceptions of work environment conditions that either help } \\
\text { or hinder learning, supervisors' proximate support for } \\
\text { learning, and satisfaction with workplace learning. Novices } \\
\text { and experienced specialists differ in terms of the sources } \\
\text { and methods of learning that they use. The results identify } \\
\text { the individual variables that contribute most to the } \\
\text { discrimination between the two groups. }\end{array}$ \\
\hline $\begin{array}{l}\text { Dalley \& Hamilton } \\
\text { (2000) }\end{array}$ & $\begin{array}{l}\text { Knowledge, context and } \\
\text { learning in the small } \\
\text { business }\end{array}$ & $\begin{array}{l}\text { Elaborate what is meant by the } \\
\text { "context" of the small business. } \\
\text { Reveal something of the process by } \\
\text { which "context" influences } \\
\text { "knowledge" and "learning" } \\
\text { outcomes and the effectiveness of } \\
\text { small business education and training. }\end{array}$ & $\begin{array}{l}\text { Case studies based on interviews } \\
\text { with CEOs in eight small firms. }\end{array}$ & $\begin{array}{l}\text { Learning by doing seems to be the preferred method of } \\
\text { knowledge creation in small business. Advice that conflicts } \\
\text { with the culture, communication modes and learning of the } \\
\text { small firm is destined to be ineffective. Advisers must } \\
\text { immerse themselves in the context of the small firm to fully } \\
\text { understand it. }\end{array}$ \\
\hline $\begin{array}{l}\text { Ehrich \& Billett } \\
\text { (2004) }\end{array}$ & $\begin{array}{l}\text { Learning new practices } \\
\text { in small business: } \\
\text { engagement and } \\
\text { localised support }\end{array}$ & $\begin{array}{l}\text { Discuss the findings of a study that } \\
\text { investigated how the learning of } \\
\text { innovative practices might best } \\
\text { proceed in small businesses. }\end{array}$ & $\begin{array}{l}\text { Case studies based on interviews } \\
\text { with } 30 \text { small business operators. }\end{array}$ & $\begin{array}{l}\text { The small business operatives that appeared to have learned } \\
\text { most about the Goods and Service Tax were those who } \\
\text { were highly engaged in the task of learning about the GST } \\
\text { and also accessed high levels of support from localised } \\
\text { sources. A typology comprising dimensions of support } \\
\text { needed and engagement by small business operatives was } \\
\text { synthesized. }\end{array}$ \\
\hline
\end{tabular}




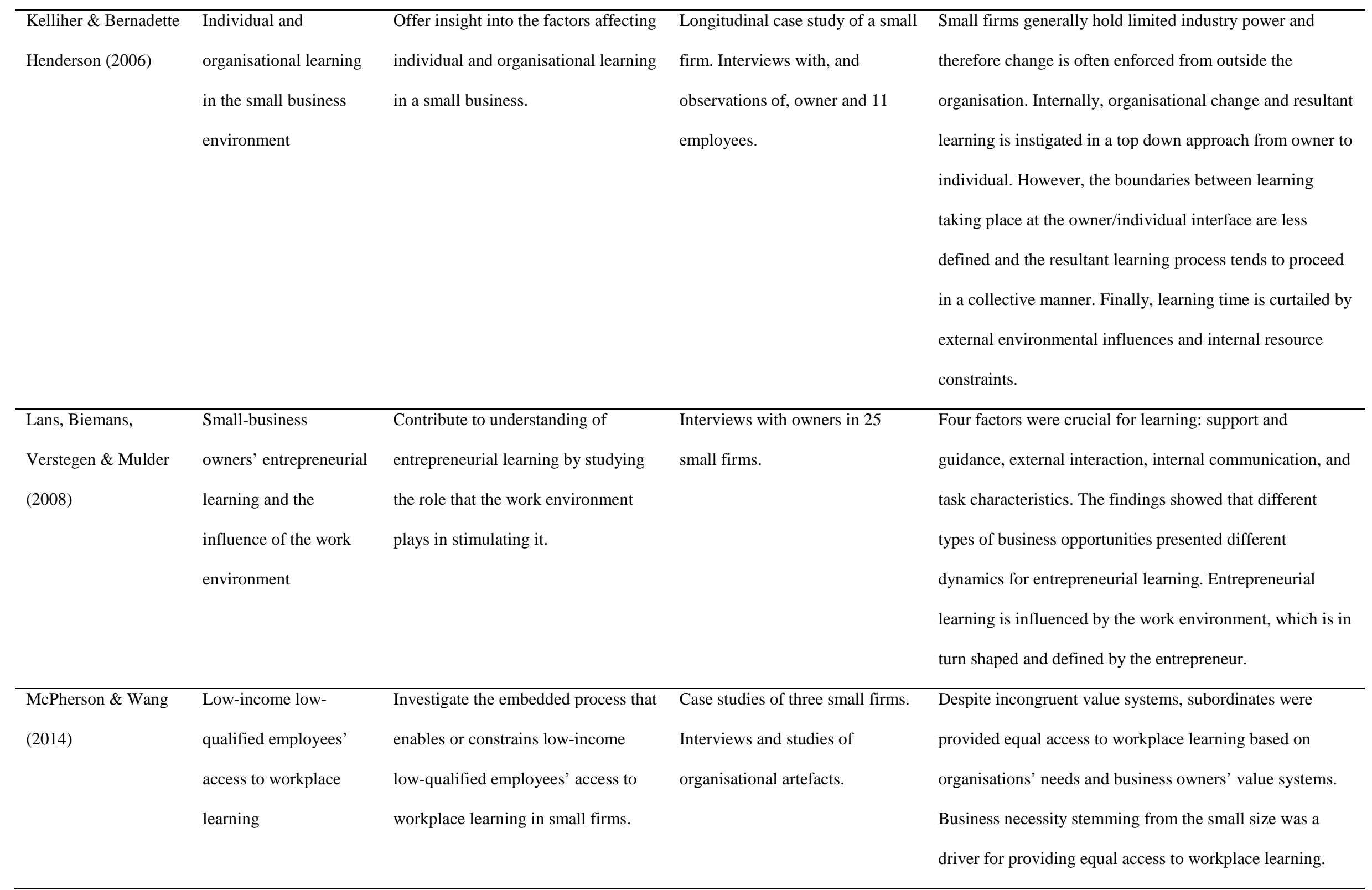




\section{Table 2:}

\section{Categories of factors and propositions}

\begin{tabular}{|l|l|}
\hline Categories of factors & Propositions \\
\hline Job characteristics: & $\begin{array}{l}\text { In small businesses, informal learning is enhanced by } \\
\text { learning embedded in everyday goal-directed work activities, } \\
\text { which tend to be characterised by high task or skill variety, } \\
\text { wide scope for action, and task significance. }\end{array}$ \\
\hline Relational characteristics: & $\begin{array}{l}\text { In small businesses, informal learning is enhanced through } \\
\text { the (a) tendency to involve family and friends as workers; (b) } \\
\text { spatial and social proximity of employees; and (c) personal } \\
\text { and frequent employer-employee interaction. }\end{array}$ \\
& $\begin{array}{l}\text { In small businesses, innovative learning is potentially } \\
\text { inhibited by family labour and the formation of homogenous } \\
\text { work groups which tend to evolve because owner-managers } \\
\text { employ informal recruitment practices. }\end{array}$ \\
\hline $\begin{array}{l}\text { Organisational } \\
\text { characteristics: }\end{array}$ & $\begin{array}{l}\text { In small businesses, informal learning is constrained by lack } \\
\text { of: (a) managerial attention to promoting informal learning; } \\
\text { (b) specialised knowledge and skills required to foster } \\
\text { informal learning; and (c) internal labour markets. }\end{array}$ \\
$\begin{array}{l}\text { In small businesses, organic structures and adhocracy are } \\
\text { facilitative of informal learning. }\end{array}$ \\
\hline
\end{tabular}




\section{Table 3:}

\section{Heuristic conceptual framework}

\begin{tabular}{|l|l|}
\hline $\begin{array}{l}\text { Workplace characteristics that } \\
\text { influence informal learning }\end{array}$ & $\begin{array}{l}\text { Distinctive small business characteristics relevant to } \\
\text { informal learning }\end{array}$ \\
\hline Job characteristics: & $\begin{array}{l}\text { Broad jobs. } \\
\text { Low specialisation. } \\
\text { Multiple roles and responsibilities. } \\
\text { Individuals can typically see results of work effort. } \\
\text { Wide scope for action. }\end{array}$ \\
\hline Relational characteristics: & $\begin{array}{l}\text { Employer-employee relationships are characterised by } \\
\text { direct face-to-face contacts. } \\
\text { Close, informal working relationships. } \\
\text { Low level of managerial formality. } \\
\text { Are often family businesses. } \\
\text { Tend to rely on family labour. }\end{array}$ \\
\hline Organisational characteristics: & $\begin{array}{l}\text { Flat, simple structures with few management layers. } \\
\text { Flexible, adaptable structures of the organic type. } \\
\text { Absence of departmental/functional 'mindset'. } \\
\text { Absence of internal labour markets. } \\
\text { Lack of internal resources. } \\
\text { Multi-tasked owner-managers. } \\
\text { Modest management know-how and skills. }\end{array}$ \\
\hline
\end{tabular}

Source: Information in the table is generated primarily from De Winne and Sels (2012); Ghobadian and Gallear (1997); Josefy, Kuban, Ireland and Hitt (2015); Kuan and Aspinwall (2004); and Maurer (2002). 